\title{
Forest offence types, trends and lapses: Case study of the Nkawie Forest District of Ghana from 2005-2010
}

\author{
Mercy A. A. Derkyi ${ }^{1}$, Ton Dietz ${ }^{2}$ \\ ${ }^{1}$ Department of Forest Science, School of Natural Resources, University of Energy and Natural Resources, P.O. Box 214 Sunyani, Brong \\ Ahafo Region of Ghana \\ ${ }^{2}$ African Studies Centre, PO Box 9555, 2300 RB Leiden, The Netherlands
}

Email address:

mercy.derkyi@uenr.edu.gh (M. A. A. Derkyi),dietzaj@ascleiden.nl (T. Dietz)

To cite this article:

Mercy A. A. Derkyi, Ton Dietz. Forest Offence Types, Trends and Lapses: Case Study of the Nkawie Forest District of Ghana from 2005-2010. Agriculture, Forestry and Fisheries. Vol. 3, No. 4, 2014, pp. 224-232. doi: 10.11648/j.aff.20140304.13

\begin{abstract}
The documented analysis of the forest offences revealed eight forest offence types with prevalent cases being chainsaw milling, illegal logging and illegal farming. Between 2005 and 2010, the district recorded 121 offences with more offences occurring in the on-reserve areas than in the off-reserve areas. The timber species, which was most exploited illegally is Triplochiton scleroxylon (wawa), a scarlet star-rated species, which is under imminent economic threat. Analyses of the official records revealed lapses in record keeping since there are no references to the outcomes of most offences, especially those relating to cases under investigation by the Police and Regional Forest Services Division. A call for capacity development of the frontline staff of the Forest Services Division at the District levels is paramount especially in detecting, collecting, entering and analyzing forest offences cases and outcomes as well as training in forest investigation and incident management. Furthermore, equipping the district offices with the requisite technological equipment like computers and accessories, software and real-time Global Positioning System (GPS) trackers will enhance effective monitoring and data management of forest resources especially when Ghana is committed in ensuring timber legality under the Voluntary Partnership Agreement.
\end{abstract}

Keywords: Forest Offences, Nkawie Forest District, Chainsaw Milling, Illegal Logging, Law Enforcement

\section{Introduction}

The fundamental components of forest governance arrangements are attributed to policy approaches and instruments, which regulate forest management to protect environmental and other forest values especially in an era where environmental and natural resource crime has significant adverse effects on ecosystems, livelihoods, and the global economy $[1,2,3]$.

In Ghana, the forest sector has an extensive range of laws that govern the management of forest resources. In practice, however, it appears that the enforcement of such laws is compounded by political and institutional challenges, which result in the prevalence of illicit forest activities that eventually lead to environmental damage, revenue loss and the destruction of livelihood sources of forest fringe communities $[4,5,6]$. Three weaknesses that undermine the regulatory and legislative instruments of Ghana forest sector are (i) non-compliance with the regulations by the sector itself, (ii) too many regulations governing the forestry sector, and (iii) low penalties for default [6]. Furthermore, weak forest law enforcement is attributed to (i) the remoteness of forested areas, (ii) the absence of a road network, or a deficient road network, which impedes movement, and (iii) a closed canopy that hinders direct observations [7]. Nevertheless, Tasmania's forest practice systems in their Forest Practices Act has recorded higher compliance and enforcement through well-designed and implemented co-regulatory approaches with emphasis also on training and education and with enforcement powers like penalties as last resort [8]. In 2008, when Ghana committed itself to the Non-Legally Binding Instrument on All Types of Forests (NLBI), one of the four key policy objectives stakeholders recommended for urgent policy consideration in order to start realizing sustainable forest management was strengthening law enforcement. This was in line with the United Nations Forestry Forum (UNFF) NLBI policy measure resolution 6(n), which states, 'Review, and as needed, improve forest-related legislation, 
strengthen forest law enforcement and promote good governance at all levels in order to support sustainable forest management, to create an enabling environment for forest investment and to combat and eradicate illegal practices according to national legislation, in the forest and other related sectors' [9]. In an effort to achieve this policy objective, one of the strategies proposed is to document forest offences in the NLBI monitoring and evaluation framework as a baseline for monitoring illegal forest activities and as a means of checking whether existing measures have led to a minimization of these offences [10]. It is also worth mentioning that Ghana's voluntary partnership agreement (VPA) with the European Union is in line with this objective through enforcement of law via legality of assurance and compliance systems [11].

Against this background, this paper aims to contribute insights that will support the national objective to strengthen law enforcement by analyzing forest offences types, trends and identify institutional challenges in the Nkawie forest district for policy consideration.

The specific questions addressed in this paper are:

1. What politics govern the Nkawie Forest District regarding institutional and legislation frameworks?

2. What types of forest offences prevail, how are the trends from 2005-2010 and the lapses thereof?

The paper is based on secondary analysis of forest politics in Ghana and the analyses of official forest offence records at the Nkawie Forest District from 2005-2010.

\section{Methodology}

\subsection{Study Area}

The Nkawie Forest District is one of seven forest districts in the Ashanti region under the jurisdiction of the Forest Services Division of the Forestry Commission. The Forest District headquarters is at Nkawie, about a forty-five minute drive from Kumasi, the capital of the Ashanti Region. The forest district covers six political districts, namely Atwima Nwabiagya, Atwima Mponua, Atwima Kwawoma, Bosomtwi, Ahafo-Ano South and Ahafo-Ano North. The Nkawie Forest District shares common boundaries with eight other forest districts, namely Bechem and Offinso Forest Districts in the north, Juaso Forest District in the east, Kumawu Forest District in the northeast, Goaso, Bibiani and Sefwi Wioso Forest Districts in the west, and Bekwai Forest District in the southwest.

Six forest reserves are managed by the Nkawie Forest District covering a total area of $1,019.72 \mathrm{~km}^{2}$. These are
Asenayo, Desiri, Jimira, Offin Shelter, Tano-Offin and Tinte Bepo forest reserves. All the reserves are vested in the Golden Stool (i.e. the Asantehene) under the care of some stools who act as caretakers, as shown in Table 1.

Table 1. The forest reserves, total area and perimeter in the Nkawie Forest District

\begin{tabular}{lcc}
\hline Forest Reserve & Total area $\left(\mathbf{k m}^{\mathbf{2}}\right)$ & Total perimeter $\mathbf{( k m )}$ \\
\hline Asenanyo & 227.92 & 100.26 \\
Desiri & 150.95 & 63.46 \\
Jimira & 62.85 & 49.78 \\
Offin Shelterbelt & 60.23 & 40.26 \\
Tano-Offin & 402.23 & 117.90 \\
TinteBepo & 115.54 & 64.62 \\
Total & 1019.72 & 436.28 \\
\hline
\end{tabular}

Source: Nkawie Forest Services Division info-sheet (2010).

\subsection{Data Collection and Analysis}

The study gathered data using secondary and official data sources. The secondary data sources were gathered from official documents of the District FSD and the Forestry Commission laws to understand the politics governing the forest resources in the Nkawie forest district and the laws governing forest offences in Ghana. The study further employed unobtrusive method in collecting data from the official records of forest offences from 2005 to 2010. This kind of data collection offers an opportunity for longitudinal research to analyze the trends and connection over time [12]. The variables of interest were: i) type of offences recorded during the period and its distributions; ii) the species in relation to timber related offences; iii) size of cleared forest lands in terms of land use offences such as forest farming. Other variables included the occurrences of the offences with regards to tree species, species names, offences outcomes and the ecological importance of tree species harvested in respect to the star rating system. Ghana's star rating system indicates conservation priorities for timber species as follows: green $=$ no threat of extinction; pink $=$ significantly exploited but no threats yet to their economic future; red $=$ current rates of exploitation present a significant danger of economic extinction; scarlet $=$ under imminent threat of economic extinction [13].

The secondary data were content analysed while the official data sources were analysed using thematic coding based on the variables using SPSS. Data were descriptively analyzed and inferences made such as offence types and number of offence cases from 2004-2010 as shown in Table 2.

Table 2. Occurrence of forest of offence types in the district from 2005-2010

\begin{tabular}{|c|c|c|c|c|c|c|c|}
\hline \multirow{2}{*}{ Offence type } & \multicolumn{6}{|c|}{ Number of offence cases from 2005-2010 } & \multirow{2}{*}{ Total } \\
\hline & 2005 & 2006 & 2007 & 2008 & 2009 & 2010 & \\
\hline Sawn lumber (chainsaw milling) & 24 & 9 & 9 & 8 & 1 & 2 & 53 \\
\hline Illegal logging & 12 & 9 & 6 & 9 & 7 & 7 & 50 \\
\hline Illegal farming & 4 & 0 & 1 & 1 & 1 & 2 & 9 \\
\hline Others* & 2 & 0 & 1 & 2 & 1 & 3 & 8 \\
\hline
\end{tabular}

*Including charcoal burning, canoe carving, illegal mining (galamsey), human-induced wildfire and deliberate destruction of plantations. 


\section{Results}

\subsection{Politics Governing the Forest Resources}

The Nkawie Forest District, which is headed by a manager and two assistant managers, is responsible for the management of forest reserves at the micro level. The range supervisors and forest guards are the frontline officials in direct and frequent contact with the local communities and the timber operators. As far as forest management is concerned, the District FSD monitors and regulates the harvesting of forest resources, especially timber, in reserve and off-reserve areas. With regard to protection, the District FSD protects the reserves by maintaining forest reserve boundaries, preventing wildfire and taking steps to keep out illegal loggers, chainsaw millers and farmers especially in hill sanctuaries, convalescence areas, globally significant biodiversity areas (GSBAs) and along river banks. It is the mandate of the forest guards to keep reserve boundaries clear and patrol the reserve in order to prevent illegal activities. In some of these activities, the District FSD collaborates with forest-fringe communities. The range supervisors are in charge of regulating timber exploitation in a designated forest area. Using the tree information form (TIF), they conduct stock surveys and measure felled trees to estimate tree volume. Additional responsibilities are issuing $\log$ conveyance certificates to contractors and conducting post-harvesting timber inspections.
An important core activity of the District FSD is forest plantation development. This activity is carried out in collaboration with District Assemblies when plantations are established in the administrative districts, with local communities under the modified taungya system and with plantation developers under the commercial plantations scheme [14]. Another activity is forestry education, which encompasses public awareness creation. This is done in collaboration with other entities such as Radio Stations, District Assemblies, the Ghana National Fire Service and some NGOs. Topics addressed in educational and sensitization programmes include, but are not restricted to, wildfire prevention, afforestation and reforestation. The District FSD also provides technical advice to individuals or institutions who wish to engage in forestry activities such as tree nursery and plantation establishment. The Nkawie Forest District was one of the districts in which the Voluntary Partnership Agreement (VPA) with the EU to combat illegal logging was piloted as well as the site for the implementation of the Wildfire Management Act [14].

Three sets of legislation of relevance to forest offences are: (i) the Timber Resources Management Act, 1997 (Act 547) and its amended Act 617; (ii) the Timber Resources Management Regulation, 1998, (L.I. 1649), and (iii) the Forest Protection Decree 1974 NRCD 243 as amended by the Protection Amendment Act 2002, Act 624; these are presented in Box 1.

Box 1. Laws governing forest offences and their sanctions

Box 1a. The Timber Resources Management Act, 1997(Act 547), Section 17 stipulates that:

'(1) Any person charged with the management or protection of a forest resource by virtue of his employment in any institution of government who(a) By any act or omission in the performance of his duties facilitates the breach of any provision of this Act; or(b) condones or connives with any other person in breach of a provision of this Act, commits an offence and is liable on summary conviction to a term of imprisonment of not less than 6 months and not exceeding two years without the option of a fine.

(2) Any person who(a) harvests timber to which this Act applies without a valid Timber Utilization Contract; or(b) operates a vehicle to carry, haul, evacuate or transport timber harvested in contravention of this Act*, or (c) offers for sale, sells or buys timber harvested in contravention of this Act; or(d) stocks timber harvested in contravention of this Act; or(e) carries, hauls or evacuates by non-mechanical means any timber harvested in contravention of this Act, or (f) is the owner of a vehicle or not being the owner causes to be operated a vehicle to carry, haul, evacuate or transport timber harvested in contravention of this Act**, commits an offence and is liable on summary conviction to imprisonment for a term of not less than 6 months and not exceeding 2 years.

(3) Where a person is convicted under subsection (2) the court shall order the confiscation to the State of any tool, equipment and machinery involved in the commission of the offence; and the court shall order to be confiscated and sold any timber harvested in the commission of the offence.

(4) Notwithstanding the right of the court to sentence a person convicted under subsection (2) of this section to imprisonment, the court may in lieu of sentence of imprisonment impose in respect of the offences specified in-(a) subsection (2) (a) or (b), a penalty in the sum of $1000 \%$ of the market value of the timber involved in the commission of the offence; or(b) subsection (2) (c) or (d), a penalty in the sum of $500 \%$ of the market value of the timber involved in the commission of the offence; or(c) subsection (2) (e), a penalty in the sum of $100 \%$ of the market value of the timber involved in the commission of the offence.'

* As amended by the Timber Resources Management (Amendment) Act, 2002 (Act 671), s. 4(a).

** As inserted by the Timber Resources Management (Amendment) Act, 2002 (Act 617), s. 4(b).

Source: [15] 
Box 1b. Timber Resources Management Regulation, 1998, (L.I. 1649) Regulation (41) deals with the offences and declares that:

'(1) Any person who (a) obstructs an authorized person of the Forest Products Inspection Bureau or the Forestry Department in the exercise of his duties contrary to sub-regulation (2) of regulation 15 ; or (b) is found in possession of any timber product that is not properly marked or numbered contrary to sub-regulation (3) of regulation 20; or (c) is found moving or in possession of any timber without a conveyance certificate in respect of the product contrary to sub-regulation (1) of regulation 24; or (d) being the owner of a chainsaw fails to register the chainsaw with the relevant District Assembly contrary to regulation 28(1); or (e) uses a chainsaw not registered with the District Forest Officer to fell any tree or saw any timber contrary to regulation 29(1); or (f) fails to mark the stump of a tree he fells with the timber registration number contrary to regulation 33; or (g) sells or offers for sale lumber cut with a chainsaw contrary to regulation 32(2); or (h) being a landowner permits an unregistered chainsaw to be used on his land for felling trees or sawing timber contrary to regulation 34; or (i) fells or is found in possession of a restricted species of timber contrary to sub-regulation (1) of regulation 40 , commits an offence and is liable on summary conviction to a fine not exceeding $\varnothing 5$ million* (equivalent to GH $\varnothing$ 500 or US $\$ 333)^{1}$ or to imprisonment for a term not exceeding twelve months or to both, and where the offence continues to a fine not exceeding $₫ 100,000.00$ (GH $\phi 10$ or US\$ 7) for every day or part of a day during which the offence continues.

(2) Where a person fells any tree or saws any timber with an unregistered chainsaw the court shall, in addition to the punishment imposed under sub-regulation (1) of this regulation order that the chainsaw or the tree or timber products in respect of which the offence was committed be forfeited and disposed of as the court may direct. (3) Any officer who- (a) declares a false measurement of timber contrary to sub-regulation (1) of regulation 23; or (b) falsely calculates stumpage fees; or (c) assists a contractor to under declare tree volumes used in the calculation of stumpage fees; commits an offence and is liable on summary conviction to a fine not exceeding $₫ 5$ million or imprisonment for a term not exceeding 12 months and shall be liable to be dismissed from the public services.'

* The new Ghana cedi and US dollar equivalents of the old Ghana cedi were added by the authors.

Source: [15]

Box 1c. Forest Protection Decree 1974 NRCD 243 as amended by the Protection Amendment Act 2002, Act 624

1. "Any person who in a Forest Reserve without the written consent of the competent forest authority

(a) fells, uproots, lops, girdles, taps damages by fire or otherwise damages any tree or timber;

(b) makes or cultivates any farm or erects any building;

(c) causes any damage by negligence in felling any tree or cutting or removing any timber;

(d) sets fire to any grass or herbage, or kindles a fire without taking due precaution to prevent its spread;

(e) makes or lights a fire contrary to any order of the Forestry Commission;

(f) in any way obstructs the channel of any river, stream, canal or creek;

(g) hunts, shoots, fishes, poison water or sets traps or snares;

(h) subjects any forest produce to any manufacturing process or collects, conveys or removes any forest produce; or

(i) pastures cattle or permits any cattle to trespass;

commits an offence against the state and is liable to summary conviction to a fine not exceeding 500 penalty units or to imprisonment not exceeding 2 years or to both, except that for a second or subsequent offence under this section the offender shall be liable on summary conviction to a fine of not less than 250 penalty units or to imprisonment not exceeding 3 years or to both.

2. Any person who

(a) knowingly counterfeits or fraudulently uses upon timber or standing a mark or indicates that the timber or tree is the property of any person;

(b) without the written consent of a Forest Officer alters, defaces or obliterates a mark placed on any timber or tree; or

(c) alters, moves, destroys or defaces any boundary mark of any Forest Reserve;

commits an offence and is on summary conviction liable to a fine not exceeding 500 penalty units or to imprisonment not exceeding 2 years or to both, except that for a second or subsequent offence under this section the offender shall be liable on summary conviction to a fine of not less than 250 penalty units or to imprisonment not exceeding 3 years or to both.

A 'competent forest authority' means a forest officer with the rank not below Assistant District Manager who is able to take decisions on behalf of the Executive Director of the Forest Services Division or the Chief Executive of the Forestry Commission."

Source: [15]

${ }^{1}$ Exchange rate was then \$1 equivalent to GH 1.5 


\subsection{Forest Offence Types in the District from 2005-2010}

A review of the forest offences records in the Nkawie Forest District indicated a total of 121 offence cases in the six forest reserves and the off-reserve areas from 2005-2010. Of these cases, twenty (17\%) occurred in the off-reserve area, whereas $101(83 \%)$ occurred in the six forest reserves. The most frequently recorded offence type was chainsaw milling (44\%) followed by illegal logging $(41 \%)^{2}$ and illegal farming $(7 \%)$. The other cases $(8 \%)$ were charcoal burning (1\%), canoe carving $(2 \%)$, illegal mining $(2 \%)$, human induced wildfire $(2 \%)$ and intentional destruction of established timber plantations (1\%).

\subsection{Trend of the Forest Offences from 2005-2010}

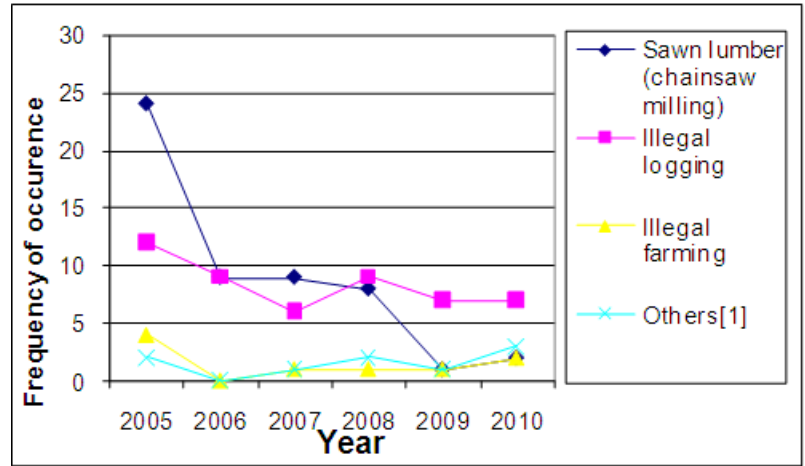

Figure 1. Trend in the number of recorded forest offences in Nkawie Forest District

Figure 1 shows the various offences in the specific years. In 2005 the Nkawie Forest District recorded 24 chainsaw milling cases. In the subsequent years, fewer offences were recorded, a trend that is also evident for the other offence types. In 2005, four cases of illegal farming were recorded, with no such incidences in 2006 and incidental incidences in subsequent years.

\subsubsection{Offence Related to Chainsaw milling (Number of Cases $=53$ )}

Of the 53 recorded chainsaw milling offences cases, $79 \%$ occurred in the six forest reserves, with the Tano-Offin forest reserve recording the highest number of cases $(n=17)$, and $21 \%$ were reported from the off-reserve area. Generally, those who were arrested were fined by the FSD, while the lumber, chainsaws and vehicles carrying the illegal lumber were confiscated. Confiscated lumber is generally auctioned. In some cases, offenders absconded while others were arrested by the police or the FSD military team. The majority of cases $(n=35)$ were dealt with through police investigation and administrative means available to the FSD. In sixteen of the recorded cases, the culprits absconded,

${ }^{2}$ Illegal logging refers to the removal of trees from the forest without a Timber Utilization Contract or Timber Utilization Permit; chainsaw milling refers to the on-site conversion of logs into sawn wood for commercial purposes using chainsaws [16]. although the FSD managed to confiscate the lumber and some of the chainsaw machines. Only two cases were sent to the district court for judgment, where the offenders were sentenced to a fine of $\mathrm{GH} \varnothing 250$ (\$167) and $\mathrm{GH} \varnothing 400$ (\$267) respectively in 2005 . The records showed that offence cases related to chainsaw milling are charged under Act $547 \mathrm{sec} 17$ (2) (a) and (b) and its amended Act 624 Sec 1(a) (h) (Box 1a).The three most common trees felled by these offenders were Triplochiton scleroxylon (Wawa), Piptadeniastrum africanum (Dahoma) and Khaya spp. (African mahogany), which fall under the scarlet and red star rating respectively (Table 3). A total of 102 tree species were reported to be sawn during these periods. In thirteen cases, both on and off-reserve, records did not indicate the tree species types felled by the culprits.

Table 3. Types of tree species sawn into lumber (2005-2010) ( $n=40$ cases)*

\begin{tabular}{|c|c|c|c|}
\hline Scientific name & $\begin{array}{l}\text { Trade/local } \\
\text { name }\end{array}$ & $\begin{array}{l}\text { No. of } \\
\text { trees/logs } \\
\text { felled }\end{array}$ & Star rating** \\
\hline $\begin{array}{l}\text { Triplochiton } \\
\text { scleroxylon }\end{array}$ & Wawa & 40 & Scarlet \\
\hline $\begin{array}{l}\text { Piptadeniastrum } \\
\text { africanum }\end{array}$ & Dahoma & 17 & Red \\
\hline Khaya spp. & $\begin{array}{l}\text { African } \\
\text { mahogany }\end{array}$ & 9 & Scarlet \\
\hline $\begin{array}{l}\text { Mansonia } \\
\text { altissima }\end{array}$ & Oprono & 8 & Red \\
\hline Aningeria spp. & Asenfena & 6 & Scarlet \\
\hline Milicia excels & Odum & 5 & Scarlet \\
\hline $\begin{array}{l}\text { Nesogordonia } \\
\text { papaverifera }\end{array}$ & Danta & 5 & Pink \\
\hline $\begin{array}{l}\text { Chrysophyllum } \\
\text { albidum }\end{array}$ & Akasaa & 3 & Red \\
\hline $\begin{array}{l}\text { Terminalia } \\
\text { superba }\end{array}$ & Ofram & 3 & Red \\
\hline $\begin{array}{l}\text { Entandrophragma } \\
\text { angolense }\end{array}$ & Edinam & 2 & Scarlet \\
\hline $\begin{array}{l}\text { Turraeanthus } \\
\text { africanus }\end{array}$ & Avodire & 1 & \\
\hline Ceiba pentandra & Onyina & 1 & Red \\
\hline $\begin{array}{l}\text { Terminalia } \\
\text { ivorensis }\end{array}$ & Emire & 1 & Scarlet \\
\hline Antiaris toxicaria & Kyenkyen & 1 & Red \\
\hline Cola gigantean & Waterpuo & 1 & Pink \\
\hline $\begin{array}{l}\text { Entandrophragma } \\
\text { cylindricum }\end{array}$ & Sapele & 1 & Scarlet \\
\hline
\end{tabular}

\subsubsection{Offence Related to Illegal Logging (Number of Cases $=50$ )}

From 2005-2010, fifty cases of illegal logging were reported. The majority of the cases $(82 \%)$ were recorded in the on-reserve areas with Tinte Bepo reserve recording most cases and Desiri forest reserve having no reported cases in this offence type.Similar to illegal chainsaw milling, Act $547 \sec 17$ (2) (a) and (b) is the main law that applies to the arresting, prosecuting and fining of perpetrators of this illicit activity. In three of the cases, the offenders were arrested and prosecuted in the law courts. The records indicate that two culprits attracted fines of between $\mathrm{GH} \varnothing 200$ and $\mathrm{GH} \varnothing 300$ (US\$ 133 and US\$ 200). The number of logs confiscated 
was three logs of kyenkyen (Antiaris toxicaria) in the Tano-Offin reserve and five logs (i.e.bako (Tieghemella heckelii), papao (Afzelia Africana) and African mahogany (Khaya spp.)) in the Offin Shelterbelt in 2005. The third case occurred in the Tano-Offin reserve, which involved the exploitation of four logs of wawa (Triplochiton scleroxylon) (Table 4). The case was sent to court. The offence record mentions a second hearing in 2005, but no outcome of that hearing was stated in the report. According to the records, thirty-one cases were under police investigation, of which 15 referred to culprits who had absconded. The FSD used administrative means to deal with the other 16 cases. In other words the offenders were arrested, fined and some logs auctioned. Some of the cases involved legal timber operators who were fined by the FSD mainly because their vehicles carried illicit logs. In these cases, the FSD deflated the tyres of the vehicles in order to prevent movement. As in the case of chainsaw milling, wawa was the most felled tree species. In this offence type wawa was followed by odum (Milicia excels) and onyina (Ceiba pentandra) as shown in Table 4. Over these years, the total number of trees recorded in the district in relation to illegal logging was 413 , comprising twenty-seven timber species. The star ratings of these species were scarlet (eleven species), red (eight species), pink (five species) and green (two species) (Table 4).

Table 4. Tree species exploited under illegal logging (2005-2010

\begin{tabular}{|c|c|c|c|}
\hline Scientific name & local name & Trade name/ No. of trees/logs felled & Star rating \\
\hline Triplochiton scleroxylon & Wawa & 168 & Scarlet \\
\hline Milicia excels & Odum & 37 & Scarlet \\
\hline Ceiba pentandra & Onyina & 28 & Red \\
\hline Piptadeniastrum africanum & Dahoma & 22 & Red \\
\hline Antiaris toxicaria & Kyenkyen & 21 & Red \\
\hline Pterygopta macrocarpa & Koto & 19 & Scarlet \\
\hline Nesogordonia papaverifera & Danta & 15 & Pink \\
\hline Terminalia superba & Ofram & 13 & Red \\
\hline Khaya spp. & African mahogany & 13 & Scarlet \\
\hline Entandrophragma utile & Utile & 11 & Scarlet \\
\hline Tieghemella heckelii & Bako & 10 & Scarlet \\
\hline Celtis mildbreadi & Esa & 9 & Pink \\
\hline Aningeria spp. & Asenfena & 8 & Scarlet \\
\hline Entandrophragma cylindricum & Sapele/ Penkwa & 9 & Scarlet \\
\hline Mansonia altissima & Oprono & 5 & Red \\
\hline Chrysophyllum albidum & Akasaa & 5 & Red \\
\hline Albizia ferruginea & Awiemfosamna & 4 & Scarlet \\
\hline Daniella ogea & Hyedua & 4 & Scarlet \\
\hline Petersianthus macrocarpus & Esia & 3 & Pink \\
\hline Cylicodiscus gabunensis & Denya & 2 & Pink \\
\hline Lovoa trichiliodes & Dubinibiri & 2 & Red \\
\hline Afzelia africana & Рараo & 2 & Red \\
\hline Klainedoxa gabonensis & Kroma & 1 & Green \\
\hline Albizia zygia & Okoro & 1 & Green \\
\hline Distemonanthus bentamianus & Bonsamdua & 1 & Pink \\
\hline
\end{tabular}

Under the chainsaw milling and logging offence types, eight and eleven scarlet species respectively had been exploited between 2005 and 2010. This contributes to a loss of timber revenues to the state since these trees were taken illegally and not all of the culprits were arrested and fined for the state to generate revenue. Equally exploited species are those of red and pink star rating, which face potential economic extinction. Only two species (i.e. Klainedoxa gabonensis and Albizia zygia) of the trees felled under illegal logging are less valuable species with a green star rating. Illegal logging and chainsaw milling thus create a potential of losing high economic value timber species if access to these resources is not well regulated by the mandated institution.

\subsubsection{Offence Related to Illegal Farming in the Forest Reserves (Number of Cases $=9$ )}

Nine cases of illegal farming were recorded in four of the reserves namely Tano-Offin, Desiri, Asenanyo and Tinte
Bepo. The total recorded area cleared for farming was 166 ha over the period of 2005-2010. There was one case in the Tano-Offin forest reserve in which the area of the cleared forest was not stated but covered large tracts in six compartments. From these nine cases, one offender was sent to the Nyinahin community tribunal and was fined $\mathrm{GH} \varnothing 300$ (US\$ 200). Four culprits were arrested and handed over to the police with confiscated chainsaws. In some cases, the culprits were arrested and handed over to the regional FSD office for investigation, while their farms were destroyed. The legislation for the prosecution of offenders were the NRCD 243 (amended Act 642) sec 1 (1b) (see Section 7.3.2) and Act 547 sect 17. Sub. Sec. 2 (a) (Box 1c \&1a). There were also four cases in which the offenders could not be apprehended but the farms were destroyed. In such instances, surveillance was put in place to arrest any culprit. In some reserves where national plantations are being established, the cleared areas are being replanted to replace lost stocks. The outcomes of the nine offences are presented in Table 5. 
Table 5. Illegal farming offence outcomes from 2005-2010

\begin{tabular}{ll}
\hline Offence outcome & Number of case* \\
\hline Culprit sent to court with fine & 1 \\
Cases under police investigation & 2 \\
$\begin{array}{l}\text { Cases resolved by administrative means } \\
\text { (destruction of farms, converting it into a } \\
\text { national forest plantation) }\end{array}$ & 6 \\
\hline
\end{tabular}

* The reporting system does not indicate names of the culprits.

\subsubsection{Other Offence Types (Number of Cases=9)}

The other offence types are made up of four categories that occurred sporadically. These were offences related to canoe carving $(\mathrm{n}=2)$, charcoal burning $(\mathrm{n}=2)$, human-induced wildfire incidence $(n=2)$, deliberate destruction of plantations $(n=1)$ and illegal mining $(n=2)$. With regard to canoe carving cases occurred in both the Tano-Offin Globally Significant Biodiversity Area (GSBA) and Asenayo forest reserve in 2010 with the carving of 10 canoes whose owners absconded. The Tano-Offin GSBA offence case was charged under the NDPC $243 \mathrm{sec}$ (1) (a) (amended Act 642), whereas that of Asenayo was under Act 547 Sec. 17 sub-sec 2(a). Since the culprits absconded, the matter was reported and preparations made for the auctioning of the canoes. Two cases of charcoal production were reported in the offence records of 2005 in the Asenayo and Desiri forest reserves. The culprit in one of the cases was handed over to the police for prosecution. The outcome of the investigation since 2005 is not reflected in the offence records. The last offence type in the next category is human-induced wildfire. The legislation applicable to this offence is the PNDC law 229. The two cases reported were all human-induced, but the culprits were never arrested. The wildfires were brought under control with the help of people from the forest-fringe communities. Another offence type was related to the intentional destruction of national forest plantations based on a personal grudge by a farmer. This led to the arrest of the offender and prosecution under Act $624 \mathrm{Sec} 1 \mathrm{Sub}$-sec. (1) (a) in the district court. As in most cases, the outcome of the court case was not indicated in the reporting system. The last offence type in this category was illegal mining, which took place in the Offin-Shelterbelt and destroyed about 4 ha of forestland. In one of the cases, the offenders had to appear in court and were fined $\mathrm{GH} \phi 300$ (\$200) whereas in the other case, which resulted in the clearing of about 0.8 ha of forest land, the offenders were sent to court. There was, however, no mention of the court outcomes.

\section{Discussion}

The Nkawie Forest District is endowed with six forest reserves categorised into different management regimes. The accessing, processing and conveying of forest resources without a permit constitutes a criminal offence as stipulated in the Act 547 (amended 617), LI.1649 and NRCD (amended 642). Thus, every illicit activity in forest reserves and off-reserve areas especially related to timber resources is treated as a criminal offence. Such a situation makes it difficult to assess what is criminal and not criminal when it comes to people's livelihood needs. There is an indication that compliance with law enforcement is difficult especially when offences are entangled with issues of tenure [7]. However, is it a crime to access forest resources to meet one's livelihood needs? It has been argued that such questions make it difficult for local people to acknowledge that what the law says is a crime and they perceive that as injustice [17]. According to the same author, they respond to the perceived injustice by 'a culture of conspiracy' and by violating forest laws, 'as either an act of defiance or a desperate attempt at achieving subsistence' [17:16]. As indicated in the literature, policy implementation is always challenged because it is not just a mechanical translation of stated goals into activities, but rather influenced and mediated by multi-stakeholder perceptions and attitudes [18].Lessons could be drawn from Tasmania's Forest Practices Act, which uses a co-regulatory approach complemented by training and education, self-monitoring and reporting with enforcement powers being the last resortto improve compliance and enforcement in the sector [8]. The documented forest offences revealed eight forest offence types with prevalent cases being chainsaw milling, illegal logging and illegal farming. These offences confirm the conflict types reported by the local communities around Tano-Offin forest reserve in relation to forest and tree livelihood conflicts [19].

Between 2005 and 2010, the district recorded 121 offences with more offences occurring in the on-reserve areas than in the off-reserve areas. These contrast with the findings in a similar study in three forest districts in the Brong Ahafo region where more offences tend to occur in off-reserve areas than in on-reserve areas [20]. The difference between the two studies could be due to the different location of the study areas with peculiar needs of inhabitants and ease of access to on-reserve and off-reserve forests. Nonetheless, both studies have highlighted the fact that the timber species, which is most exploited illegally is Triplochiton scleroxylon (wawa), a scarlet star-rated species, which is under imminent economic threat.

There is empirical evidence that large numbers of cases are resolved by the FSD through the imposition of fines and the subsequent release of vehicles associated with the particular forest offence. For example, the FSD uses several approaches to resolve illegal farming offences within forest reserves. The illegal forest farms are often destroyed and the subsequent measure involves three strategies: the culprit is sent to the police station and the matter ends there, or the offence is dealt with by the FSD officials at the regional or district level, or the offender is arrested and prosecuted in court and fined. The use of administrative sanctions in civil law to deal with natural resource offences without judicial involvement is acceptable in countries like the United States [4], but is harder to implement in 
developing countries. An alternative procedure is what is called 'compounding', in which case an executive body (like the FC) is empowered to levy fines without involvement of the court [7:149]. In order for the FC to legally exercise its administrative powers, the FC needs to be empowered by an administrative Act to guide its actions and enable it to have a standard prosecuting or fining mechanism across its jurisdiction in the country. As this study made clear, most of the cases reported in court had either no evidence or inadequate evidence since the offenders absconded, making it difficult to present such cases in the law court under criminal penalty. Evidence of the violation of law is an essential ingredient before one can be sentenced to a fine or imprisonment. Article 19 (2) (c) of the Constitution of Ghana clearly states that ' $A$ person charged with a criminal offence shall be presumed to be innocent until he is proven or has pleaded guilty'. Assigning prosecuting powers to the FC could help solve the impunity of forest offences, provided measures are taken to prevent non-transparent charges and corruption.

Analyses of the official records revealed lapses in record keeping since the outcomes of offences, especially regarding cases under police and regional FSD investigations are not indicated. This makes it difficult to assess whether actions taken against these offenders actually have a positive impact on the level of offences in the district. Even though there has been a decline in recorded forest offences from 2005 to 2010, this decline may be due to the (in) efficiency of the FSD monitoring system or to the FC's incapacity to detect the offenders and record the offences. A call for capacity development of FC officials, both staff trained at university level and field officers may be essential as has also been recommended by forest governors and experts [21]. In South Carolina in the United States, for instance, the Forestry Commission officers are trained and certified in criminal justice in addition to training in forest law, forest investigation and incident management. Law enforcement therefore becomes part of the training of the forest manager and somehow this is missing in the current training of forest managers in Ghana's forest sector. The legal department of the FC could extend its mandate from representing the $\mathrm{FC}$ in legal matters to advocacy for the FC to establish a prosecuting system $^{3}$ as well as building capacities of FC officials in legal issues and conflict management. There is also a need for officials of the legal department to have knowledge of natural resource management in addition to knowledge of law, so that they have a better and more in-depth understanding of the negative environmental effects of forest offences and how best to quantify them during presentation of cases in the law courts. Furthermore, equipping the districts offices with the requisite technological equipment like computers and accessories,

\footnotetext{
${ }^{3}$ The Ghana Forestry Commission is now having a prosecution training programme for its staff, which is a positive step in minimizing forest offences (GNA, March, 19th, 2013).
}

software and real-time Global Positioning System (GPS) trackers will enhance effective monitoring and data management of forest resources especially when Ghana is committed in ensuring timber legality under the Voluntary Partnership Agreement.

\section{Conclusion}

This study revealed that there is a broad range of legislation, which governs the forest sector Ghana in ensuring effective governance processes. Nevertheless, the implementation of these laws is challenged because of the prevalence of forest offences and low fines attached to these offences, coupled with institutional challenges of properly recording these offences. There is a clear indication of sizeable number of scarlet, red and pink timber species illegally exploited between 2005 and 2010, which contributes to environmental damage in addition to loss of timber revenues to the state. Illegal logging, chainsaw milling and illicit farming thus contribute to losing high economic value timber species if access to these resources is not effectively regulated. However, this will only be achievable if the mandated institution pays much attention to the capacity development of its frontline staff in terms of training and logistics to facilitate monitoring of the resources and data management. Furthermore, tertiary institutions in charge of training natural resource practitioners could contribute to minimizing forest offences through integrating law enforcement courses such as forest investigation, prosecution procedures and incident management in the curriculae in addition to engaging law practitioners as guest lecturers to make law enforcement an integral component of the training of the natural resource manager.

\section{Acknowledgements}

The authors are grateful to Tropenbos International (TBI) who funded this research, which was carried out under the TBI Ghana programme. Thanks to Dr. Mirjam Ros-Tonen and Dr. Kyereh Boateng for their guidance to make the first author's $\mathrm{PhD}$ a reality. Appreciation also goes to the Nkawie Forest District for providing the data on forest offences. The authors also acknowledge the valuable comments provided by two anonymous reviewers on the earlier draft of this paper.

\section{References}

[1] C.L. McDermott, B. Cashore and P. Kanowski, (2010). Global Environmental Forest Policies: An International Comparison. Earthscan, London, 2010, p.372.

[2] B. Cashore, Key components of good forest governance, Exlibris. ASEAN-German ReFOP Project, the Analysis and Making of Regional Public Policy. Discussion Paper No.6, July 2009 (2009). 
[3] K. Sander, J. Lee, V. Hickey, V. B. Mosoti, J. Virdin and W.B. Magrath, Conceptualizing maritime environmental and natural resources law enforcement - The case of illegal fishing. Environmental Development (In press). Available online 10 August, 2013- DOI: 10.1016/j.envdev.2013.08.002

[4] E. Larbi, J. Yankson, E.S. Annag, B.K. Acheampong and F.A. Koomson, Judicial attitude towards forest related offences in the Nkawie Forest District of Ghana. Unpublished LLB thesis, Kwame Nkrumah University of Science and Technology (KNUST), Kumasi, Ghana. 2011.

[5] E. Nutakor, E. Marfo and P.O. Tutu, Socio-political constraints to the enforcement of forest laws: A case study of chainsaw operations in Ghana. Ghana J. Forestry 27: 2436, 2011.

[6] K.A. Oduro, V.K. Agyeman andK. Gyan, Implementing timber legality assurance regime in Ghana: A review of stakeholders concerns and current institutional constraints Ghana J. Forestry 27(2):1-10, 2011.

[7] L.C. Christy, C.E. DiLeva, J.M. Lindsay and P.T. Takoukam, Forest law and sustainable development: Addressing contemporary challenges through legal reform. Law, Justice and Development series. Washington, D.C.: World Bank, 1997, p.206.

[8] G.R.Wilkinson, M. Schofield and P. Kanowski, Regulating forestry - Experience with compliance and enforcement over the 25 years of Tasmania's forest practices system. Forest Policy and Economics 40, 1-11, 2014.

[9] UNFF-United Nations General Assembly, Resolution adopted by the general assembly on Non-legally binding instrument on all types of forest. Sixty-second session agenda item 54, 2008.

[10] Forestry Research Institute of Ghana (FORIG) (2010), Development of a monitoring and evaluation system for non-legally binding instrument (NLBI) on all types of forests in Ghana, 2010, p.141.

[11] Ghana-EU VPA, Annual Report: Implementing the Ghana-EU Voluntary Partnership Agreement, 2011, p.19.
[12] A. Bryman, Social Research Methods. Oxford University Press. 3rd edition, 2008, p.

[13] W. D. Hawthorne and M. Abu-Juam, Forest protection in Ghana with particular reference to vegetation and species. Gland, Switzerland, and Cambridge, UK: IUCN, 1995, p.220.

[14] NFSD Info-sheet on the Nkawie Forest Services Division, 2010 (unpublished).

[15] Ghana Forestry Commission (undated) http://76.12.220.51/library.php?id=15 (accessed 6 October 2011)

[16] E. Marfo, Chainsaw milling in Ghana: context, drivers and impacts. Wageningen, the Netherlands: Tropenbos International, 2010, p.80.

[17] K.S. Amanor, Equity in forest benefit sharing and poverty reduction. In: K.S. Nketiah, J.A.S. Ameyaw and B. Owusu, eds, Equity in forest benefit sharing: Stakeholder Views, pp. 15-23, 2005. Tropenbos International-Ghana (2005). Workshop proceedings 3, October 29, 2004. Wageningen, the Netherlands: Tropenbos International.

[18] S. Vasan, Ethnography of the forest guard contrasting discourses, conflicting roles and policy implementations. Economic and political weekly, special articles 5, 4125-4133, 2002.

[19] M. Derkyi, M.A.F.Ros-Tonen, B. Kyereh, B. and T. Dietz, Emerging Forest Regimes and Livelihoods in the Tano Offin Forest Reserve, Ghana: Implications for Social Safeguards. Forest Policy and Economics 32: 49-56, 2013.

[20] Abugre, S. and F.P. Kazaare, Trends and status of illegal timber logging in three forest districts of BrongAhafo region of Ghana. Ghana Journal of Forestry 26: 89-100, 2010.

[21] M.A.A Derkyi, Fighting over forest: interactive governance of conflicts over forest and tree resources in Ghana's high forest zone. African Studies Collection; issue: 41, Leiden, 2012 , p.319. 